\title{
EXPRESSIONS OF GENES IN Triticum aestivum L. VARIETIES UNDER SOME ABIOTIC STRESSES
}

\author{
ŞENGÜL TORAMAN, P. - ERGÜN, N.* \\ Hatay Mustafa Kemal University, Science and Art Faculty, Biology Department, Antakya, \\ Hatay, Turkey \\ ${ }^{*}$ Corresponding author \\ e-mail: ergun.nuray@gmail.com \\ (Received 22 $2^{\text {nd }}$ Aug 2020; accepted $16^{\text {th }}$ Apr 2021)
}

\begin{abstract}
Abiotic stresses caused by changing climatic conditions affect plants not only physiologically but also at the molecular level. This study, Triticum aestivum L. cv. Dağdaş-94 and Doğankent were divided into four groups at the end of the sixth day. The seedlings were exposed to flood, drought, and salt stress and harvested at the end of the twelfth day. Increased catalase enzyme, ascorbate peroxidase, and glutathione reductase activities were noted in Doğankent cultivar under drought stress conditions. Proline accumulation was mostly observed in Dağdaş-94 variety, exposed to drought stress. The chlorothricin $(C H L)$ gene has been investigated in many plants and was examined first in Triticum aestivum in this study. Triticum aestivum salt-related hypothetical protein (TaSRHP) increased in both wheat varieties. This gene is dependent on salinity. Although the exact mechanism is not known exactly, the absence of amplification in Triticum aestivum zinc finger protein (TaZnFP) - which is known to occur under stress - suggests that it may be the result of reading on the twelfth day of the study, and this protein may appear as the first response to stress. It can be stated through this study; Dağdaş-94 variety is more drought-resistant than Doğankent variety.
\end{abstract}

Keywords: stress, proline, antioxidant enzymes, CHL, TaSRHP, TaZnFP

\section{Introduction}

Today, human and animal nutrition is largely based on cereals, especially wheat (Triticum aestivum L.). Turkey has a rich variety of plants due to soil structure and location. The wheat plant has a high nutritional value and workability in different ways. Turkey has become one of the largest gene centres. Wheat's resistance to stress conditions, diseases and pests is considered its quality and this diversity is important for wheat growing (Dirik et al., 2020).

The life of the plant is dependent on the soil. Due to global environmental changes, the soil is frequently exposed to abiotic stresses, such as salinity, drought, submerging, low and high temperature, ultraviolet radiation, nutrient deficiency, and metal toxicity (Hasanuzzaman et al., 2019).

Irregular water intake, caused by a lack of it for example, negatively affects the growth of the plant. An anaerobic environment forms in plant roots when it is flooding. This environment is divided into two categories according to the levels of oxygen: oxygen deficient and oxygen absent (Hossain and Uddin, 2011). Oxygen absence threatens the uptake of atmospheric gases necessary for respiration and photosynthesis in plants, causing the cessation of the citric acid cycle (TCA) cycle and oxidative phosphorylation in root mitochondria (Sairam et al., 2008). Studies in flooded fields have shown that oxygen is reduced by the accumulation of matter (Mittler et al., 2004). This activates the antioxidant system in plants (Ergün and Öncel, 2012; Özçubukçu et al., 2014). 
In arid conditions, the water potential of the soil decreases, followed by that of the plant and in later stages a, fall in turgor pressure, closure of stomata, decrease in leaf growth and decrease in photosynthesis take place (Bota et al., 2004).

Salinity is one of the major problems of soils worldwide. Salt stress directly affects some metabolic activities in plants; it can kill plants by limiting biological activity such as germination, cell division, growth and development. As the salt concentration in soil, the cleavage of chlorophylls, shrinkage of thylakoids, and accretion of adjacent grana membranes are observed, and the operability of the electron transport system in thylakoids decreases significantly under salty conditions (Şen and Alikamanoğlu, 2011).

Reactive oxygen species are produced as a result of abiotic and biotic stresses, such as salinity, drought, flood, and frost stress, and herbicide applications that plants are exposed to damage membrane lipids, DNA, macromolecules such as proteins, and photosynthetic pigments.

The chlorothricin gene ( $C H L$; the gene encoding the light-harvesting chlorophyll $a / b$-binding protein) is a prerequisite for the formation of chlorophyll in plants and Mg-clamping of protoporphyrin IX into the tetrapyrrole branch (BioCyc Database Collection; Shimizu and Masuda, 2021). In this study, the presence of CHL gene in T. aestivum was examined for the first time, and gene data were obtained by Kolukirık (2014; Table 1). This gene is known to be important in the formation of the chloroplast organelle, which performs photosynthesis in plants and many species close to plants during the evolutionary process (Mayfield and Taylor, 1984). This gene found in different plants is named differently. In Arabidopsis thaliana sp., it is called CHLI1-CHL11 (BioCyc Database Collection), and in Zostera marina L., it is named light-harvesting chlorophyll a/b-binding ( $L H C$ ) proteins (Kong et al., 2016). LHC genes are highly conserved in the evolutionary process, and the classification of ZmLhc genes indicates that it is consistent with the evolutionary position of $Z$. marina. The real-time reverse transcription-polymerase chain reaction (RT-PCR) analysis showed that different ZmLhca and ZmLhcb members respond to stress in different patterns of expression, and salinity, temperature, light intensity, and light quality can affect the expression of most ZmLhca and ZmLhcb genes (Kong et al., 2016).

Table 1. Names, code names, sequences, and product sizes of primers expressed in abiotic stress conditions used in this study

\begin{tabular}{c|c|c|c}
\hline Primer & Left primer (5’) & Right primer (3') & Reference \\
\hline CHL (chlorothricin) & CCT CGA CTACCT & AAG AAG CCG AAC \\
CGG CAA C & ATG GAG AA & $(2014)$ \\
\hline $\begin{array}{c}\text { TaSRHP (Triticum aestivum salt-related } \\
\text { hypothetical protein) }\end{array}$ & CGG CCG CGA CAC & GGT CGC CGG GAA \\
CTT CAT A & GCA CTT & Hou (2013) \\
\hline $\begin{array}{c}\text { TaZnFP (Triticum aestivum zinc finger } \\
\text { protein) }\end{array}$ & $\begin{array}{c}\text { GGA AGC CAA GCA } \\
\text { ACC ATG TG }\end{array}$ & $\begin{array}{c}\text { GGC TAC CGT GGC } \\
\text { ACT AGG AG }\end{array}$ & $\begin{array}{c}\text { Min et al. } \\
(2013)\end{array}$ \\
\hline
\end{tabular}

T. aestivum salt-related hypothetical protein $(T a S R H P)$, is a stress-related gene that can occur in plants exposed to stress (salinity, drought, cold, etc.) (Hou et al., 2013) (Table 1). The overexpression of TaSRHP in A. thaliana cv., the wild species, showed development by greater resistance against both salt and drought stress in Columbia (Hou et al., 2013). This study aimed to shed light on the TaSRHP gene. 
T. aestivum zinc finger protein (TaZnFP) is a transcription factor that is stimulated in cold, salinity, and drought stresses and as a result of the abscisic acid application (Min et al., 2013). Although the working mechanism is not yet fully known, the TaZnFP transcript factor shows an increase in control in drought and salinity stress conditions in the Arabidopsis plant.

Therefore, in this study, salt, flood, and drought stresses were applied to the wheat seedlings (T. aestivum L. cv. Doğankent and Dağdaş-94), and the physical changes that occurred were examined. Identifying the relationship between wheat varieties and various stress factors antioxidant enzymes (catalase enzyme [CAT] and glutathione reductase [GR] activities) and the amount of free proline were investigated by spectrophotometric method, some genes and proteins that are active under stress $(C H L$, TaSRHP and TaZnFP) the significance levels of inhibition were examined and clarified by PCR method. At the end of the study, it was aimed to determine the gene expression, enzyme, and other metabolic activities of wheat varieties having a high tolerance to flooding, salinity, and drought stresses. The most important pigment in plants chlorophyll which is the presence with the $C H L$ gene expression and in other plants to what extent it affects the plant under which conditions it is our priority to investigate.

\section{Materials and methods}

\section{Materials}

As plant material, wheat seeds (T. aestivum L. cv. Doğankent and Dağdaş-94) were used in this study. The wheat seeds were obtained from the Eastern Mediterranean Agricultural Research Institute (Adana/Turkey). The Dağdaş-94 wheat variety is resistant to drought and cold stresses (Doğru and Ergün, 2021).

\section{Plant growing conditions}

Plastic pots with a diameter of $20 \mathrm{~cm}$ were used in plant cultivation. These pots were filled with a mixture of raw soil, organic fertilizer NPK (18:18:18), sand (2V/2V/1V), and air-dried soil. In each pot, 150 seeds were planted directly on the soil surface without any pre-processing and covered with a layer of soil about $1 \mathrm{~cm}$ thick. Immediately after sowing the seeds, all the pots were watered with $200 \mathrm{~mL}$ of water and taken to a plant-growing cabin. The plants were grown in the climate cabin at an average temperature of $24 \pm 2^{\circ} \mathrm{C}$, where the relative humidity was $66 \%$ and the light conditions were 1198 lux on average. Until the end of the sixth day, $100 \mathrm{~mL}$ of water was given every 2 days. On the third day, the wheat began to germinate. Each of these trials was performed jointly in different stress groups. After the sixth day, four different groups were formed, which are as follows:

1) Normal water application (control): The application of $100 \mathrm{~mL}$ of water every 2 days from the planting of seeds was continued until the twelfth day, and growth was observed.

2) Flood: Sowing was done in pots supported by waterproof nylon bags. It was irrigated, as there was a $1 \mathrm{~cm}$ layer of water above the soil at the end of the sixth day. It was ensured that the layer of water remained above the ground level until the twelfth day.

3) Drought: Normal irrigation application was made until the sixth day. After the sixth day, there was no irrigation until the twelfth day. 
4) Salinity $(0.7 \% \mathrm{NaCl})$ : The soil of the plants in this group was thoroughly mixed by adding $0.7 \% \mathrm{NaCl} w / \mathrm{w}$ before being filled in the pots. To prevent the inhibition of seed germination with salt effect, a 1-cm-thick layer of salt-free soil was formed on the surface, and the seeds were planted on this soil. Irrigation continued by the end of the twelfth day; it was watered as in normal water application. The plants were harvested by removing them from pots at the end of the twelfth day.

After harvesting, the shoot parts of the seedlings were cut into small pieces for analyses, labelled according to the group number of the seedlings, and stored at $-80^{\circ} \mathrm{C}$ in a deep freezer. The GR activity was measured according to Çakmak and Marschner (1992) and Çakmak (1994). The CAT activity was measured at $240 \mathrm{~nm}$ using a spectrophotometer because of the fragmentation rate of $\mathrm{H}_{2} \mathrm{O}_{2}$. The reaction mixture $(1 \mathrm{ml})$ consisted of; $50 \mathrm{mM}$ phosphorus buffer ( $\mathrm{pH}$ 7.6), $0.1 \mathrm{mM}$ EDTA, $100 \mathrm{mM} \mathrm{H}_{2} \mathrm{O}_{2}$, and enzyme extract (Çakmak and Marschner, 1992). The ascorbate peroxidase (APX) activity was measured according to Asada (1992), taking into account the decrease in absorbance due to ascorbic acid oxidation at $290 \mathrm{~nm}$ wavelengths. Free proline extraction and determination was made according to Bates et al. (1973).

Measurement of gene expressions made with wheat leaf samples exposed to drought, flooding and salt stresses. Then, leaf samples were collected after harvesting and placed in liquid nitrogen. The samples were stored at $-80^{\circ} \mathrm{C}$ until RNA analyses were performed. For total RNA isolation and reverse transcription, about $1 \mathrm{~g}$ of wheat leaves were divided into small pieces and taken into a 2-ml tube; these analyses were performed considering the study of Ergün et al. (2014).

In this study, $C H L$, TaSRHP ans TaZnFP gene expressions of wheat were performed by the service of Bio-eksen R\&D. Quantitative real-time PCR $(Q-P C R)$ protocol: The Biospeedy Relative Count Kit (Turkey) was used to determine the expression levels of genes in 12 wheat samples exposed to different stress factors. All the genes were studied in three replicates, and Livak and Schmittgen (2001) method were used for the experiment.

The kit included target genes of the $C H L$ gene encoding the light-harvesting chlorophyll $a / b$-binding protein, TaSRHP, and TaZnFP. EFA was used as the housekeeping gene, which encodes a protein in wheat, to normalize the expression levels of target genes. The kit included primers specific to the housekeeping and target genes as well as the enzymes and buffers required for the RT-PCR analysis.

The Roche LC 96 RT-PCR instrument (Roche, Switzerland) was employed for all reactions. The reaction contained $1.5 \mathrm{mM} \mathrm{MgCl}_{2}, 0.2 \mathrm{mM}$ Dinucleotittriphosphate $(\mathrm{dNTP})$ mix, $1 \times$ reaction buffer, $0.1 \mathrm{U}$ FastStart Taq DNA polymerase, $1 \times$ EvaGreen, $4 \mathrm{ng} / \mu \mathrm{L}$ of template $\mathrm{cDNA}$, and $0.5 \mu \mathrm{M}$ of each primer. In the instrument, the annealing temperatures specific to the primer pairs (Table 1) and optimized reaction cycle temperatures were used. During Q-PCR, melt curve analysis was performed only between $65^{\circ} \mathrm{C}$ and $98^{\circ} \mathrm{C}$ to ensure only the desired product was amplified. Q-PCR data were analysed by Roche Lightcycler 96 software (v.1.1).

For statistical regression analysis, the related SPSS package program was used, and the variance analysis was performed using the MacAnova program. The Fisher least significant test was used to compare the mean of threshold cycles $(\mathrm{Ct} ; p<0.05)$. The differences between the results were determined by the Duncan test according to the homogeneity between variances (Table 2). 
Table 2. Flood, drought, salt stresses (Triticum aestivum cv. Dağdaş and Doğankent) variance analysis results

\begin{tabular}{c|c|c|c|c|c|c}
\hline Parameters & CAT & GR & APX & PROLINE & CHL & TaSRHP \\
\hline Wheat & $0.000^{* *}$ & $0.000^{* *}$ & 0.44 & $0.038^{*}$ & $0.000^{* *}$ & $0.000^{* *}$ \\
\hline Stress & $0.000^{* *}$ & $0.001 * *$ & $0.005^{*}$ & $0.000^{* *}$ & $0.000^{* *}$ & $0.000^{* *}$ \\
\hline Wheat*stress & $0.001 * *$ & $0.014 *$ & $0.000^{* *}$ & $0.000 * *$ & $0.000 * *$ & $0.000^{* *}$ \\
\hline
\end{tabular}

** Significant at 0.01 level, * Significant at 0.05 level

\section{Results}

\section{Effects on the CAT, APX, and GR activities}

The CAT activity was observed to cause a significant increase in Dağdaş-94 seedlings, especially those with high-stress tolerance (Yumurtac1 and Uncuoğlu, 2012). It was noticed that drought and salt stress increase by approximately the same extent (by 50\%) according to control $(p \leq 0.01)$. Doğankent seedlings were found to decrease in flood and drought stress, whereas they increased in salt stress. The CAT activity of Dağdaş-94 seedlings, which is known to be resistant, increased more than that of Doğankent seedlings (Fig. 1).

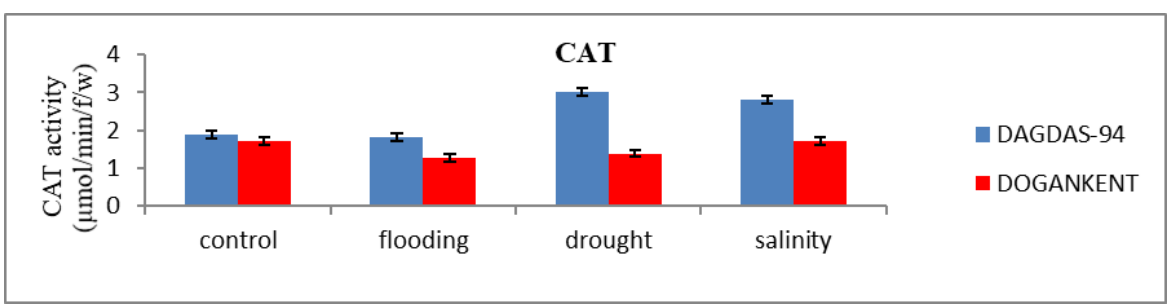

Figure 1. Changes in the average catalase enzyme activities in the wheat seedlings (Triticum aestivum cv. Dağdaş-94 and Doğankent) grown under flood, drought, and salt applications $(n=3)$

In our study, during the GR activity, there was a noticeable increase in the seedlings of all two varieties in stress conditions, especially in Doğankent seedlings $(p \leq 0.01)$. In flood and drought stress to the same degree and the GR activity in seedlings exposed to salt stress by $200 \%$ caused an increase $(p \leq 0.01)$. In Dağdaş-94 seedlings, an increase in enzyme activity was observed in all three stresses according to control, and this increase in seedlings under flood stress increased by $100 \%$ ( $p \leq 0.01$; Fig. 2 ).

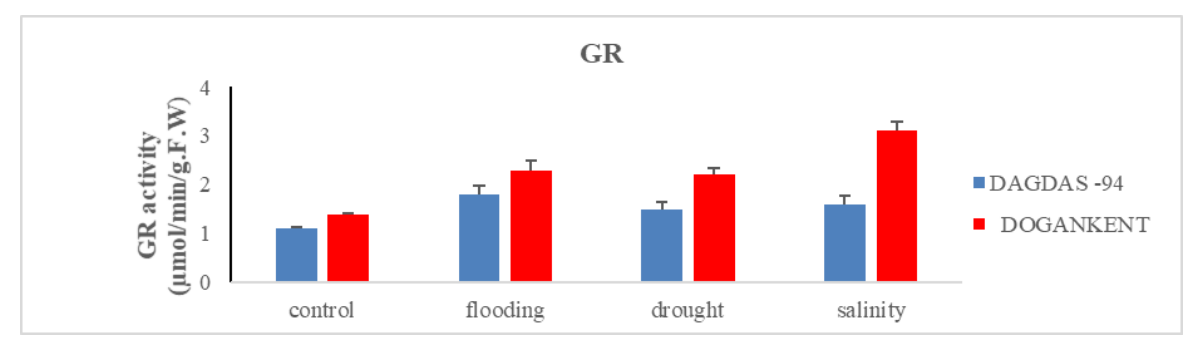

Figure 2. Effects of the wheat seedlings (Triticum aestivum cv. Dăgdaş-94 and Doğankent) grown under flood, drought, and salt applications to the average glutathione reductase (GR) activity $(n=3)$ 
The APX activity increased in all three stresses applied according to control in the seedlings of both wheat varieties $(p \leq 0.01)$. The maximum APX activity was noted in Dağdaş-94 seedlings exposed to flood and salinity stress $(p \leq 0.01)$. In Doğankent seedlings, an increase in the APX activity was observed in all three stresses according to control, and the most increase was observed in salt stress (Fig. 3).

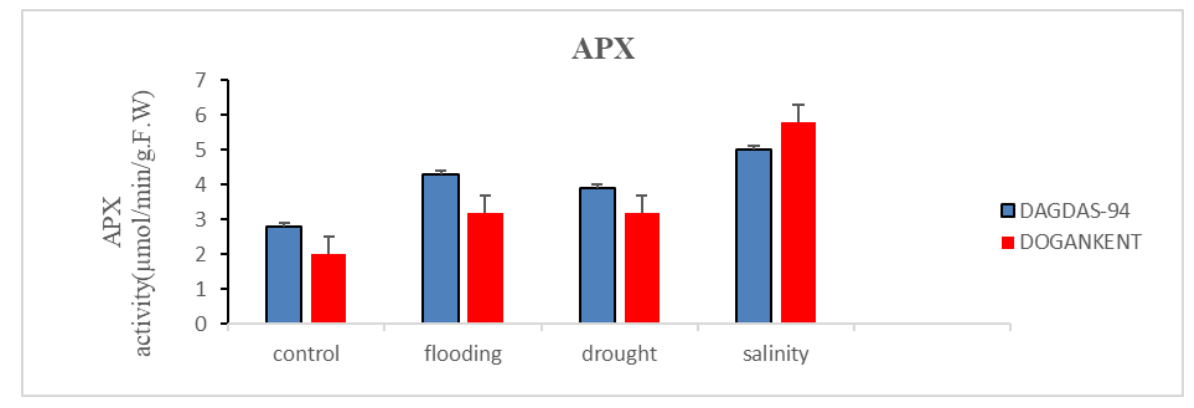

Figure 3. Effects of the wheat seedlings (Triticum aestivum cv. Dağdaş-94 and Doğankent) grown under flood, drought, and salt applications to the average ascorbate peroxidase (APX) activity $(n=3)$.

\section{Proline content}

Proline accumulation in drought, flood, and salt applications increased in Doğankent and Dağdaş-94 seedlings $(p \leq 0.05)$. The maximum proline accumulation was observed in drought stress according to the control in Dağdaş-94 seedlings $(p \leq 0.001)$. This is thought to be due to the proline being a hydrophilic amino acid. In Doğankent seedlings, the control rate is more than that in Dağdaş-94 seedlings. The maximum proline activity in this plant has been observed to increase equally in the least salinity, flood, and drought stresses (Fig. 4).

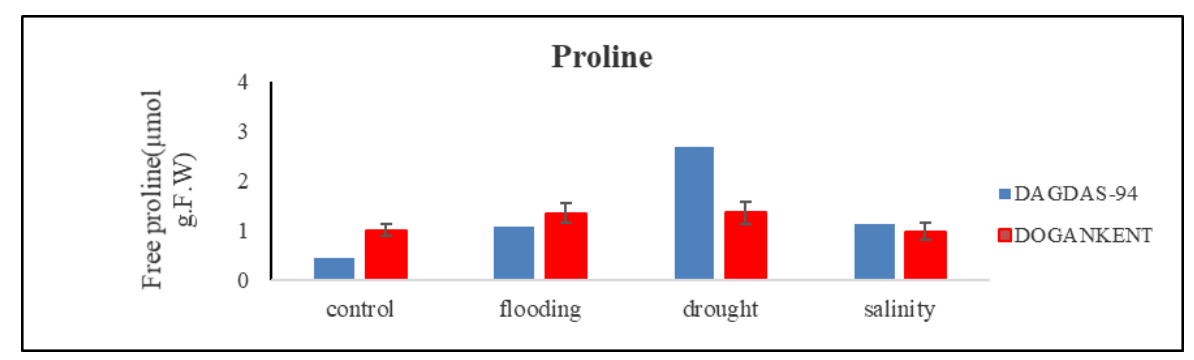

Figure 4. Changes in the amounts of free proline in the wheat seedlings (Triticum aestivum cv. Dağdaş-94 and Doğankent) grown under flood, drought, and salt applications $(n=3)$

\section{Gene expressions}

In the study, the mRNA transcriptions in wheat seedlings exposed to flood, drought, and salinity stresses were studied in quantitative mRNA analyses performed by the realtime RT-PCR method. A total of three primers thought to be associated with abiotic stresses were used in the study, and the names and sequences of the genes are given in Table 1. The expression of these primers and relative values of the results of the RT-PCR analysis are shown in Table 1. 


\section{CHL gene}

The expression of $C H L$ gene was more active in the control group Dağdaş-94 seedlings than in Doğankent seedlings $(p<0.01)$. This gene activity has been found to decrease in both types of wheat seedlings exposed to abiotic stress (Fig. 5). In Doğankent seedlings, it was observed that the greatest reduction in this gene activity decreased according to control in salinity stress. In this case, chlorophyll biosynthesis can be said to be most affected by salinity stress.

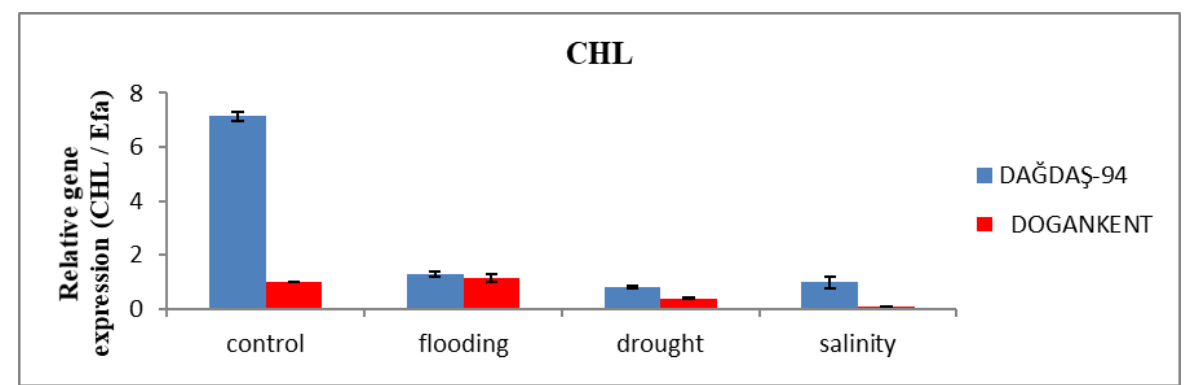

Figure 5. Changes in the amounts of chlorothricin (CHL) gene in the wheat seedlings (Triticum aestivum cv. Dağdaş-94 and Doğankent) grown under flood, drought, and salt applications $(n=3)$

The $C H L$ gene primer used in the study was made by Mustafa Kolukırık (2014) (Bioeksen R \& D) by taking the Arabidopsis plant as an example. It has been stated that $C H L$ gene primers play a role in chlorophyll syntheses and that the gene activity decreases under stress conditions. When both varieties studied were taken into account, it was determined that the expression of $C H L$ gene decreased in all three abiotic stress conditions, but this decrease occurred more in the wheat seedlings of Doğankent variety than Dağdaş-94 variety $(p \leq 0.01)$. In this case, it has been observed that the Doğankent variety is more sensitive than the Dağdaş-94 variety under all three stress conditions.

\section{TaSRHP gene}

The expression of TaSRHP gene showed amplification in the control group but did not cause any amplification in Doğankent seedlings $(p \leq 0.01)$. It was observed that the TaSRHP gene activity decreased in the Dağdaş-94 seedlings exposed to abiotic stress and was not even active in salinity stress and increased in Doğankent seedlings because of abiotic stress $(p<0.01)$. The TaSRHP gene expression activity was found to be maximum in salinity stress, as reflected in its name (Fig. 6). It has been observed that these gene values are statistically significant under different stress conditions and among wheat varieties $(p<0.01)$.

\section{TaZnFP gene}

Considering that the mechanism of TaZnFP is not yet fully determined, in this study, no amplification of the TaZnFP gene was found in the Doğankent and Dağdaş-94 seedlings under stress conditions. It was concluded that the stages of RNA isolation and cDNA synthesis from wheat samples were successful because of results in the housekeeping gene $(E F A)$ and other genes and that there was no mRNA-encoding TaZnFP in the resulting cDNA pool. It has been observed that $C H L$, TaSRHP values are 
statistically significant under different stress conditions and among wheat varieties $(p<0.01)$.

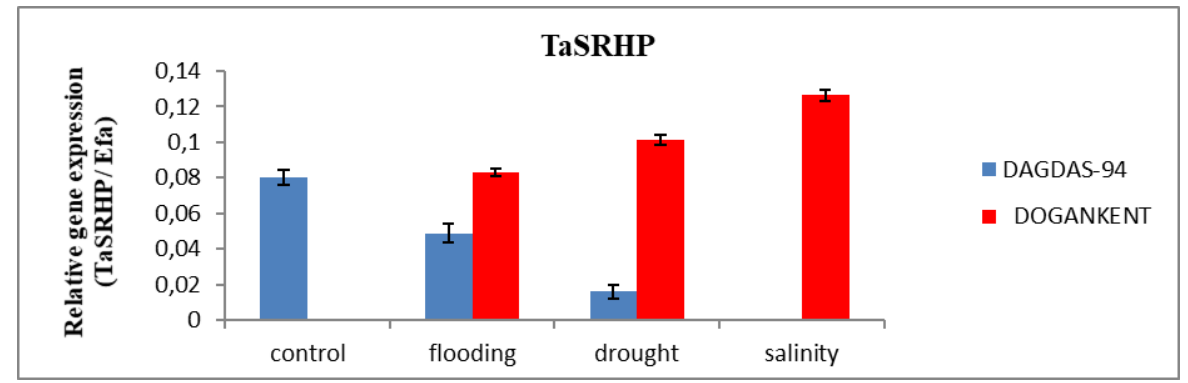

Figure 6. Changes in the amounts of Triticum aestivum salt-related hypothetical protein (TaSRHP) genes in the wheat seedlings (T. aestivum cv. Dağdaş-94 and Doğankent) grown under flood, drought, and salt applications $(n=3)$

\section{Discussion}

In this study, the drought and salt applications of Dağdaş-94 and Doğankent seedlings showed increased activity of all three enzymes. It was determined that the CAT activity is higher in Dağdaş-94 seedlings, which is known to have high drought tolerance than Doğankent seedlings. Özçubukçu et al. (2014) reported that antioxidant enzyme activity significantly increased in flood-exposed wheat seedlings. Sen and Alikamanoğlu (2011) found that it is responsible for salinity stress in antioxidant enzyme activities such as superoxide dismutase (SOD), CAT, and APX and increases it. Çelik and Atak (2012) found that while there was no significant change in the CAT activity as a result of salt stress in tobacco plants, there were increases in the GR activity. When antioxidant enzymes were active under stress conditions, plants with higher tolerance showed a higher and more durable appearance in this case.

Proline accumulation and stress tolerance correlation have been reported in several studies (Ergün and Öncel, 2012; Özçubukçu et al., 2014). Keleş and Öncel (2002) applied salt to the wheat genotype and determined a decrease in the amount of proline. In their study, Ergün et al. (2014) observed that proline accumulation was created in response to plants under various stress conditions. In our study, there was an increase in proline accumulation in both varieties. The greatest increase was observed in Dağdaş-94 seedlings subjected to drought stress. This indicates that the Dağdaş-94 variety is drought resistant.

It was determined that the $C H L$ gene played a role in chlorophyll synthesis and that this gene activity decreased under abiotic stress conditions (Grafe et al., 1999). Parallel to our study, we have shown that the light-harvesting chlorophyll $a / b$-binding (LHCB) proteins are positively involved in protective cell signalling in drought stress (Liu et al., 2013). Because the expression of $C H L$ gene can be lead to tolerant of Dağdaş-94 seedlings, it has been observed that it is more active in Dağdaş-94 seedlings than in Doğankent seedlings. In Doğankent seedlings, this gene activity decreases according to control, and this decrease was observed to be at maximum salinity stress.

TaSRHP is specific to the species of T. aestivum and is a protein that plays a role in salt stress and has emerged as a hypothesis under stress conditions. This stress gene is known to differ according to the variety and region of the plant (Hou et al., 2013). In our study, the expression of TaSRHP gene showed amplification in Dağdaş-94 seedlings in 
the control group, but it was observed that it did not cause any amplification in Doğankent seedlings. In the seedlings exposed to abiotic stress, this protein activity decreased in Dağdaş-94 seedlings and increased in Doğankent seedlings. The increase of TaSRHP, a protein specific to salt stress, in Doğankent seedlings suggests that Doğankent seedlings are more resistant to salt stress. The work we have done may shed light on other studies that can be done in this area.

It has been determined that Doğankent and Dağdaş-94 seedlings under stress do not express the TaZnFP gene. Min et al. (2013) showed that TaZnFP overexpressed under stress conditions in T. aestivum $\mathrm{cv}$. However, the $\mathrm{CCCH}$-type zinc finger proteins to which TaZnFP belongs are a large family, and there has been reported to be insufficient information on the diversity and function of these proteins. They estimated that there are about $70 \mathrm{CCCH}$-type zinc finger proteins in A. thaliana (Wang et al., 2008). Although many of these proteins have been predicted to be active in abiotic and biotic stress resistance, the reaction of very few of them to stress under different conditions has been studied. One reason why the expression of $\mathrm{TaZnFP}$ could not be determined in this study is that the wheat varieties used could activate another $\mathrm{CCCH}$-type zinc finger protein in response to stress. Another possibility is that Min et al. (2013) found that this protein is expressed in the twelfth hour. We showed that in the samples taken at the end of the sixth day, the TaZnFP gene was not expressed. Accordingly, it is thought that TaZnFP can be used as the first response mechanism created against stress in the short term and that it may lose its effect in the long term. It is thought that the presence of this protein in the wheat genome can be thoroughly investigated and used in breeding studies to determine the level of its effect under stress conditions.

\section{Conclusion}

This study is important in terms of determining answers to the molecular factors of drought, flood, and salinity stresses in two types of bread wheat seedlings (Dağdaş-94 and Doğankent), which are widely produced in our country.

It has been determined that plants subjected to abiotic stress - especially flood, drought, and salinity stress - may differ depending on the type and age of the plant and duration of stress. Because plants can develop tolerance to stress factors, it is critical to know the physiological and molecular mechanisms that enable this situation. It is aimed to use the genes we used in our study, especially the $C H L$ gene, as a source in future studies and to be present in studies on wheat breeding. And shed light on the studies to be carried out by stating that the $C H L$ gene plays a role in abiotic stresses and can lead to reductions in chlorophyll biosynthesis. The corresponding identification and mapping of genes in wheat breeding are necessary to improve the availability of them.

Acknowledgements. This study is an MSc thesis of Pelin Sengul and funded by Scientific Research Projects Coordinator (BAP) of Hatay Mustafa Kemal University (10683). Authors for very thankful to Mustafa Kolukırık (Bio-eksen R\&D) for designing CHL gene primer first found in wheat and the others primers and real-time PCR analysis. We thankful to late Prof. Dr. Suat Şahinler for his assistance in the statistical analysis of this study and we remember him with respect. 


\section{REFERENCES}

[1] Asada, K. (1992): Ascorbate peroxidase-a hydrogen peroxide-scavenging enzyme in plants. - Physiologia Plantarum 85(2): 235-241.

[2] Bates, L. S., Waldren, R. P., Teare, I. D. (1973): Rapid determination of free proline for water-stress studies. - Plant and Soil 39(1): 205-207.

[3] Bota, J., Medrano, H., Flexas, J. (2004): Is photosynthesis limited by decreased Rubisco activity and RuBP content under progressive water stress? - New Phytologist 162(3): 671681.

[4] Cakmak, I. (1994): Activity of ascorbate-dependent $\mathrm{H}_{2} \mathrm{O}_{2}$-scavenging enzymes and leaf chlorosis are enhanced in magnesium-and potassium-deficient leaves, but not in phosphorus-deficient leaves. - Journal of Experimental Botany 45(9): 1259-1266.

[5] Cakmak, I., Marschner, H. (1992): Magnesium deficiency and high light intensity enhance activities of superoxide dismutase, ascorbate peroxidase, and glutathione reductase in bean leaves. - Plant Physiology 98(4): 1222-1227.

[6] Çelik, Ö., Atak, C. (2012): The effect of salt stress on antioxidative enzymes and proline content of two Turkish tobacco varieties. - Turkish Journal of Biology 36(3): 339-356.

[7] Dirik, K. Ö., Saygilı, İ., Özkurt, M., Sakin, M. A. (2020): Examining of Salt Stress Tolerance of Some Local Bread Wheat (Triticum aestivum L.) Genotypes at Early Growth Stage. - Turkish Journal of Agriculture-Food Science and Technology 8(3): 688-693.

[8] Doğru, H., Ergün, N. (2021): Effects of cadmium - salt interactions on growth and some genes in wheat. - Applied Ecology and Environmental Research 19(2): 1019-1031.

[9] Ergün, N., Öncel, I. (2012): Effects of some heavy metals and heavy metal hormone interactions on wheat (Triticum aestivum L. cv. Gun 91) seedlings. - African Journal of Agricultural Research 7(10): 1518-1523.

[10] Ergün, N., Özçubukçu, S., Kolukirik, M., Temizkan, Ö. (2014): Effects of temperatureheavy metal interactions, antioxidant enzyme activity and gene expression in wheat (Triticum aestivum L.) seedlings. - Acta Biologica Hungarica 65(4): 439-450.

[11] Grafe, S., Saluz, H. P., Grimm, B., Hänel, F. (1999): Mg-chelatase of tobacco: the role of the subunit CHL D in the chelation step of protoporphyrin IX. - Proceedings of the National Academy of Sciences 96(5): 1941-1946.

[12] Hasanuzzaman, M., Banerjee, A., Bhuyan, M. B., Roychoudhury, A., Al Mahmud, J., Fujita, M. (2019): Targeting glycine betaine for abiotic stress tolerance in crop plants: physiological mechanism, molecular interaction and signaling. - Phyton 88(3): 185.

[13] Hossain, M. A., Uddin, S. N. (2011): Mechanisms of waterlogging tolerance in wheat: morphological and metabolic adaptations under hypoxia or anoxia. - Australian Journal of Crop Science 5(9): 1094-1101.

[14] Hou, X., Liang, Y., He, X., Shen, Y., Huang, Z. (2013): A novel ABA-responsive TaSRHP gene from wheat contributes to enhanced resistance to salt stress in Arabidopsis thaliana. - Plant Molecular Biology Reporter 31(4): 791-801.

[15] Keleş, Y., Öncel, I. (2002): Response of antioxidative defence system to temperature and water stress combinations in wheat seedlings. - Plant Science 163(4): 783-790.

[16] Kolukırık, M. (2014): Bioeksen Research \& Development Technologies. - Istanbul Technical University.

[17] Kong, F., Zhou, Y., Sun, P., Cao, M., Li, H., Mao, Y. (2016): Identification of lightharvesting chlorophyll a/b-binding protein genes of Zostera marina $\mathrm{L}$. and their expression under different environmental conditions. - Journal of Ocean University of China 15(1): 152-162.

[18] Liu, R., Xu, Y. H., Jiang, S. C., Lu, K., Lu, Y. F., Feng, X. J., Wu, Z., Liang, S., Yu, Y. T., Wang, X. F., Zhang, D. P. (2013): Light-harvesting chlorophyll a/b-binding proteins, positively involved in abscisic acid signalling, require a transcription repressor, WRKY40, to balance their function. - Journal of Experimental Botany 64(18): 5443-5456. 
[19] Livak, K. J., Schmittgen, T. D. (2001): Analysis of relative gene expression data using realtime quantitative PCR and the 2- $\Delta \Delta$ CT method. - Methods 25(4): 402-408.

[20] Mayfield, S. P., Taylor, W. C. (1984): Carotenoid-deficient maize seedlings fail to accumulate light-harvesting chlorophyll a/b binding protein (LHCP) mRNA. - European Journal of Biochemistry 144(1): 79-84.

[21] Min, D. H., Zhao, Y., Huo, D. Y., Li, L. C., Chen, M., Xu, Z. S., Ma, Y. Z. (2013): Isolation and identification of a wheat gene encoding a zinc finger protein (TaZnFP) responsive to abiotic stresses. - Acta Physiologiae Plantarum 35(5): 1597-1604.

[22] Mittler, R., Vanderauwera, S., Gollery, M., Van Breusegem, F. (2004): Reactive oxygen gene network of plants. - Trends İn Plant Science 9(10): 490-498.

[23] Özçubukçu, S., Ergün, N., Ilhan, E. (2014): Waterlogging and nitric oxide induce gene expression and increase antioxidant enzyme activity in wheat (Triticum aestivum L.). Acta Biologica Hungarica 65(1): 47-60.

[24] Sairam, R. K., Kumutha, D., Ezhilmathi, K., Deshmukh, P. S., Srivastava, G. C. (2008): Physiology and biochemistry of waterlogging tolerance in plants. - Biologia Plantarum 52(3): 401.

[25] Sen, A., Alikamanoglu, S. (2011): Effect of salt stress on growth parameters and antioxidant enzymes of different wheat (Triticum aestivum L.) varieties on in vitro tissue culture. - Fresenius Environmental Bulletin 20(2): 489-495.

[26] Shimizu, T., Masuda, T. (2021): The Role of Tetrapyrrole- and GUN1-Dependent Signaling on Chloroplast Biogenesis. - Plants 10(2): 196.

[27] Wang, D., Guo, Y., Wu, C., Yang, G., Li, Y., Zheng, C. (2008): Genome-wide analysis of $\mathrm{CCCH}$ zinc finger family in Arabidopsis and rice. - BMC Genomics 9(1): 44.

[28] Yumurtac1, A., Uncuoglu, A. A. (2012): Tissue-specific responses alter the biomass accumulation in wheat under gradual and sudden salt stress. - Journal of Stress Physiology \& Biochemistry 8(4): 143-156. 